\title{
Temporary turbine and reservoir level management to improve downstream migration of juvenile salmon through a hydropower complex
}

\author{
Stéphane Tétard ${ }^{1,2, *}$, Romain Roy ${ }^{2}$, Nils Teichert ${ }^{3}$, Jocelyn Rancon ${ }^{4}$ and Dominique Courret ${ }^{5}$ \\ ${ }^{1}$ ICEO - 220 Rue des Ailes, 85440 Talmont Saint Hilaire, France \\ ${ }^{2}$ EDF R\&D LNHE - Laboratoire National d'Hydraulique et Environnement, 6 Quai Watier, 78401 Chatou Cedex, France \\ ${ }^{3}$ Laboratoire Biologie des Organismes et Ecosystèmes Aquatiques (BOREA), Muséum National d'Histoire Naturelle, CNRS FRE 2030, \\ Sorbonne Université, IRD 207, Université de Caen Normandie, Université des Antilles, Centre de Recherche et d'Enseignement sur les \\ Systèmes Côtiers, station de biologie marine de Dinard, 38 rue du Port Blanc,35800 Dinard, France \\ ${ }^{4}$ CNSS, Larma, 43300 Chanteuges, France \\ 5 Office Français de la Biodiversité - DRAS, Pôle R\&D Ecohydraulique OFB-IMFT-PPRIME, IMFT, 2 Allée du Professeur Camille \\ Soula, 31400 Toulouse, France
}

Received: 3 November 2020 / Accepted: 19 January 2021

\begin{abstract}
Developing management rules to improve downstream migration of salmon smolts in large hydropower plants is essential to limit mortality and migration delay. A 2-year telemetry study was conducted to assess the efficiency of temporary measures to enhance the safety and speed of juvenile salmon passage through the Poutès dam (Allier River, France). 124 smolts were tracked through the reservoir and downstream of the dam, during implementation of turbine modulation and/or shutdown during night and reservoir level lowering. Level lowering significantly reduced median residence time from 3.4 days to 4.4 hours. However, even with high spill during turbine modulation, the risk of smolt being drawn toward the turbines was increased at low reservoir level due to the site's configuration, greater proximity to the surface and weak repulsive effect of the rack. Moreover, results revealed that a substantial proportion of smolts can migrate during daytime and twilight during floods, even at the beginning of the migration period. Thus targeted turbine shutdown has a good potential to protect smolts, but implementation requires studies taking account of site specificities and a flexible approach.
\end{abstract}

Keywords: Atlantic salmon / downstream migration / migratory delay / operational management / turbine shutdown

Résumé - Gestion temporaire du niveau de retenue et du turbinage d'un aménagement hydroélectrique visant à protéger les smolts de saumon Atlantique. Le développement de règles de gestion pour améliorer la dévalaison des smolts de saumon au niveau des grandes centrales hydroélectriques est essentiel pour réduire les mortalités et les retards de migration. Un suivi par télémétrie a été mené pour tester l'efficacité de mesures temporaires mises en œuvre au barrage de Poutès (rivière Allier, France). Au total, 124 individus ont été suivis depuis l'amont de la retenue jusqu'à l'aval du barrage pendant la mise en œuvre de modulation ou d'arrêt du turbinage et l'abaissement du niveau de la retenue. L'abaissement a significativement diminué le temps de résidence des smolts (médiane de 3.4 jours à niveau haut contre 4.4 heures à niveau bas). En revanche, cela a augmenté le risque d'entraînement vers les turbines en raison de la configuration du site, d'une plus grande proximité de la prise d'eau avec la surface et d'un faible pouvoir répulsif de la grille. De plus, une proportion importante des poissons peut migrer de jour et au crépuscule durant les crues, même en début de période de migration. Les arrêts ciblés de turbinage ont une efficacité potentielle élevée, mais leur mise en œuvre nécessite des études tenant compte des spécificités de chaque site.

Mots clés : Saumon atlantique / dévalaison / retard migratoire / gestion opérationnelle / arrêt de turbinage

\footnotetext{
*Corresponding author: stetard@iceo-environnement.fr
} 


\section{Introduction}

Atlantic salmon (Salmo salar) is a famous anadromous species, with both juveniles (smolts) and adults undertaking long migrations between freshwater and marine habitats. Unfortunately, the species has undergone a general decline. Recruitment of the European stock has diminished almost 3-fold, from 8 to 3 million, since the early 1970s (Friedland et al., 2009). Among other threats, river fragmentation is frequently reported as the main cause of this decline (Lucas and Baras, 2001; Thorstad et al., 2008; Limburg and Waldman, 2009).

When migrating to marine habitats, smolts can encounter hydroelectric facilities and suffer direct or delayed mortality by passing through the turbines (Pracheil et al., 2016; Thorstad et al., 2017). Moreover, dams can also cause migratory delay because reduced flow velocity slows downstream migration and alters flow paths (Hansen et al., 1984; Marschall et al., 2011; Huusko et al., 2018), resulting in erratic movements and difficulty in finding reservoir outlets (Aarestrup et al., 1999; Tétard et al., 2016a; Schwinn et al., 2018). This delay can decrease smolt survival through elevated migration energy costs (Marschall et al., 2011), reduced success of passage (Nyqvist et al., 2017) and extended exposure to predation (Jepsen et al., 1998; Gauld et al., 2013; Schwinn et al., 2017). High rates of predation in lakes or reservoirs were reported in some studies. For example, Jepsen et al. (1998) found that $90 \%$ of smolts negotiating an artificial lake died, mainly due to fish $(56 \%)$ and bird predation (31\%). Migratory delay can also further lead to desmoltification (McCormick et al., 1999): i.e. smolts losing their propensity to migrate or ability to survive in saltwater. Additionally, decreased migration speed can decrease smolt survival when migration timing and optimum environmental conditions in rivers, estuaries and the coastal environment are out of phase (McCormick et al., 1998; Thorstad et al., 2012).

In the context of climate change, the need to restore longitudinal connectivity is even more crucial (Jonsson and Jonsson, 2009; Isaak et al., 2015). The thermal and hydrological regimes of rivers are significantly affected by climate change, which may impact downstream migration of smolts (Arevalo et al., 2020). Earlier migrations are already being observed in many rivers (Jonsson and Jonsson, 2014; Otero et al., 2014; Kuczynski et al., 2017). Therefore, delayed migration may adversely affect the long-term survival of the salmonid populations (Crozier and Hutchings, 2014; Morita, 2019).

Fish-passage solutions now exist, enabling quick and safe downstream migration through hydropower complexes. Recent tests on fine-spaced low-sloping racks associated to 1 or more surface bypasses showed good effectiveness and quick passage (Tomanova et al., 2017, 2018; Nyqvist et al., 2018). However, due to management issues and investment cost, these solutions are presently limited to hydropower plants (HPP) with turbine capacity up to about a hundred $\mathrm{m}^{3} \mathrm{~s}^{-1}$ (Larinier et al., 2020).

Implementation of passage solutions in large HPPs is complex and expensive (Larinier and Travade, 2002). Surface bypasses associated to conventional trashracks are usually implemented, but tests generally showed variable and limited efficiency (Ovidio et al., 2017; Tomanova et al., 2018; Larinier et al., 2020). Other solutions, using behavioral systems to guide fish, have been tested (Mueller and Simmons, 2008; Perry et al., 2014; Tétard et al., 2019) but no clear solution easily applicable to diverse locations has been determined (Williams et al., 2012). Consequently, other active solutions, such as trap-and-transport or turbine modulation/shutdown during migration peaks, are sometimes considered to mitigate the impact of dams (Thorstad et al., 2012; Stich et al., 2015; Teichert et al., 2020a). To be effective and acceptable for stakeholders, these mitigation measures need a precise forecast of migration timing, based on calendar dates or using environmental records, to limit the financial impact on hydropower generation (Teichert et al., 2020b). In most cases, these measures are implemented in conjunction with biological monitoring (telemetry, capture, etc.).

Most smolts migrate to the ocean in spring (Otero et al., 2014), but in some locations some individuals migrate outside of the peak season, especially in fall (Birnie-Gauvin and Aarestrup, 2019). "Smoltification" is controlled by photoperiod and temperature, with migration onset triggered by temperature and sometimes by discharge (McCormick et al., 1998; Thorstad et al., 2012), especially when river flow peaks occur at the beginning of the migration season (Whalen et al., 1999; Otero et al., 2014; Teichert et al., 2020a). Some studies modeling smolt migration with these environmental variables showed high predictive performance (Sykes et al., 2009; Teichert et al., 2020a), which can give credence to active solution approaches. Nevertheless, whatever the "passage" solution (active or passive), and no matter how effective it may be, some large reservoirs can cause substantial migratory delay of several days or even weeks in some locations (Venditti et al., 2000; Schwinn et al., 2017, 2019; Tétard et al., 2019; Babin et al., 2020). However, barriers, and especially hydropower regulations, typically focus only on passage efficiency and mortality (Marschall et al., 2011) with most managers and developers overlooking the potential for sublethal costs induced by migratory delay (Silva et al., 2018).

Poutès dam is located in the Upper Allier River (France), the main tributary of the Loire River. Although this hydropower dam was equipped with fish passage solutions in the late $1980 \mathrm{~s}$, a number of problems remained when the Poutès-Monistrol hydropower complex was relicensed in 2011: migratory delay for upstream and downstream migration, and difficulty for fish in using the fishways (Bach et al., 2000; Tétard et al., 2019). After several years of concerted discussions between stakeholders, it was decided to reconfigure the Poutès dam to meet ecological connectivity requirements for sediment and fish. The project included new fishways and a much lower reservoir level. ${ }^{1}$ As a first step, a scientific program helped to assess the initial impact of the Poutès dam on smolt migration before reconfiguration (Tétard et al., 2019). The beginning of construction, which was to start in 2016, was postponed until summer 2019, and temporary measures during smolt migration were needed as early as 2017 , pending the start of reconfiguration. These proposed measures were discussed with stakeholders and aimed to improve passage efficiency while minimizing residence time in the reservoir. They consisted in temporarily lowering the reservoir

\footnotetext{
${ }^{1}$ https://www.nouveau-poutes.fr/vers-le-nouveau-poutes/le-nou veau-poutes/
} 


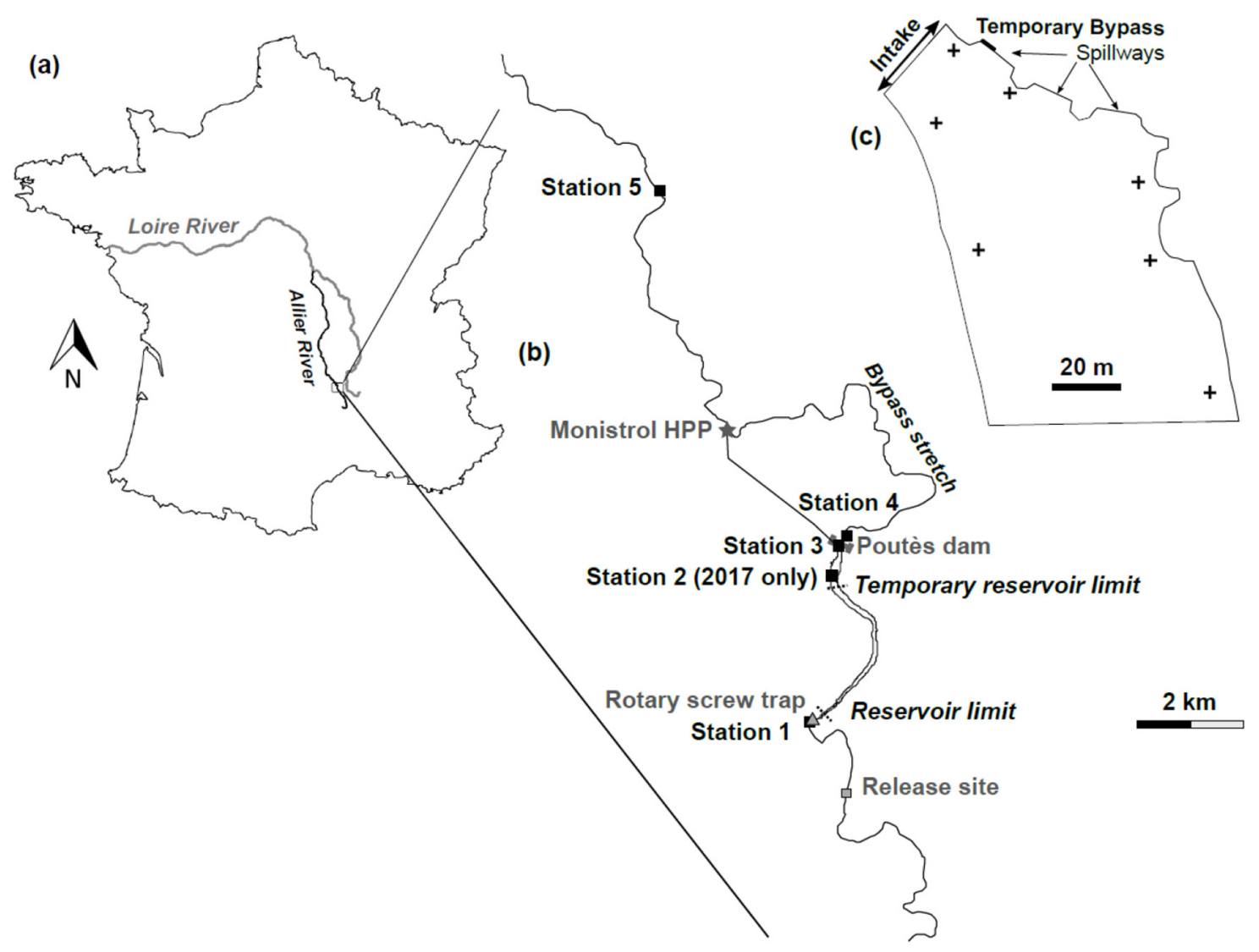

Fig. 1. Geographical location of the study area $(a, b)$ and description of the areas close to the Poutès dam (c). The crosses indicate hydrophone positions in the dam zone for the season 2017.

level to decrease migratory delay, building a temporary bypass, and modulating (in 2017) or stopping (in 2018) turbine operation.

The present study aimed to provide feedback on the successes and failures encountered during the 2 years in which management rules were implemented, based on a telemetry experiment. The temporary measures were discussed with stakeholders and continuously improved during the experiment, through a structured iterative process of "learning by doing". Comprehensive assessment of successive measures implemented at the Poutès dam thus provides feedback to guide management plans in other hydropower sites for solving issues of migratory delay and passage efficiency during smolt migration.

\section{Materials and methods}

\subsection{Study area}

The Loire River (Fig. 1) is $1012 \mathrm{~km}$ long and has a drainage area of $117,000 \mathrm{~km}^{2}$. It is the longest river system in Europe in which spawning migration of Atlantic salmon still occurs (Cuinat, 1988). The Allier River, its main tributary, is the main migration axis, with high-quality habitats for salmon reproduction (Baisez et al., 2011). Located $861 \mathrm{~km}$ from the estuary, the Poutès dam is a crucial zone for the salmon population, as upstream areas account for about $60 \%$ of the potential juvenile production of the Allier River (Minster and Bomassi, 1999). Nevertheless, since the stop of restocking in 2008 , it is estimated that only a few thousand of smolts are produced each year in upstream habitats (Bach et al., 2015). This is due to a low transfer rate of adult salmon upstream of Poutès dam so far; this situation should be significantly improved soon with the dam reconfiguration under way. The dam, $18 \mathrm{~m}$ high and $85 \mathrm{~m}$ wide, bypasses a $10 \mathrm{~km}$ river stretch of the Allier River and engenders a reservoir of $2.4 \mathrm{Mm}^{3}$ that extends over $3.5 \mathrm{~km}$ in normal conditions. The fish assemblage in the impoundment is dominated by roach (Rutilus rutilus). Common species like spirlin (Alburnoides bipunctatus), eurasian minnow (Phoxinus phoxinus), chub (Squalius cephalus), perch (Perca fluviatilis) and pike (Esox Lucius) are also found. The mean annual discharge of the Allier River is $16.6 \mathrm{~m}^{3} \mathrm{~s}^{-1}$, and mean water residence time in the impoundment is 1.67 days. The maximum flow diverted to the powerhouse is $28 \mathrm{~m}^{3} \mathrm{~s}^{-1}$. The powerhouse is equipped with three Francis turbines (\#1/2: $\left.16 \mathrm{~m}^{3} \mathrm{~s}^{-1} ; \# 3: 3 \mathrm{~m}^{3} \mathrm{~s}^{-1}\right)$; Legal minimum flow in the bypass stretch downstream of the dam is 4 or $5 \mathrm{~m}^{3} \mathrm{~s}^{-1}$, depending on the season (Tétard et al., 2019). Three spillways, each $14 \mathrm{~m}$ long, discharge floodwater.

An intake protected by a rack ( $24 \mathrm{~m}$ wide, $5.7 \mathrm{~m}$ high) is located on the left bank, between 7 and $13 \mathrm{~m}$ below the surface (in normal operating conditions), and has a gap-width of $3 \mathrm{~cm}$ (Fig. 2). A surface bypass, operating from March to June, is located on the right side of the rack. A gate automatically 
(a)

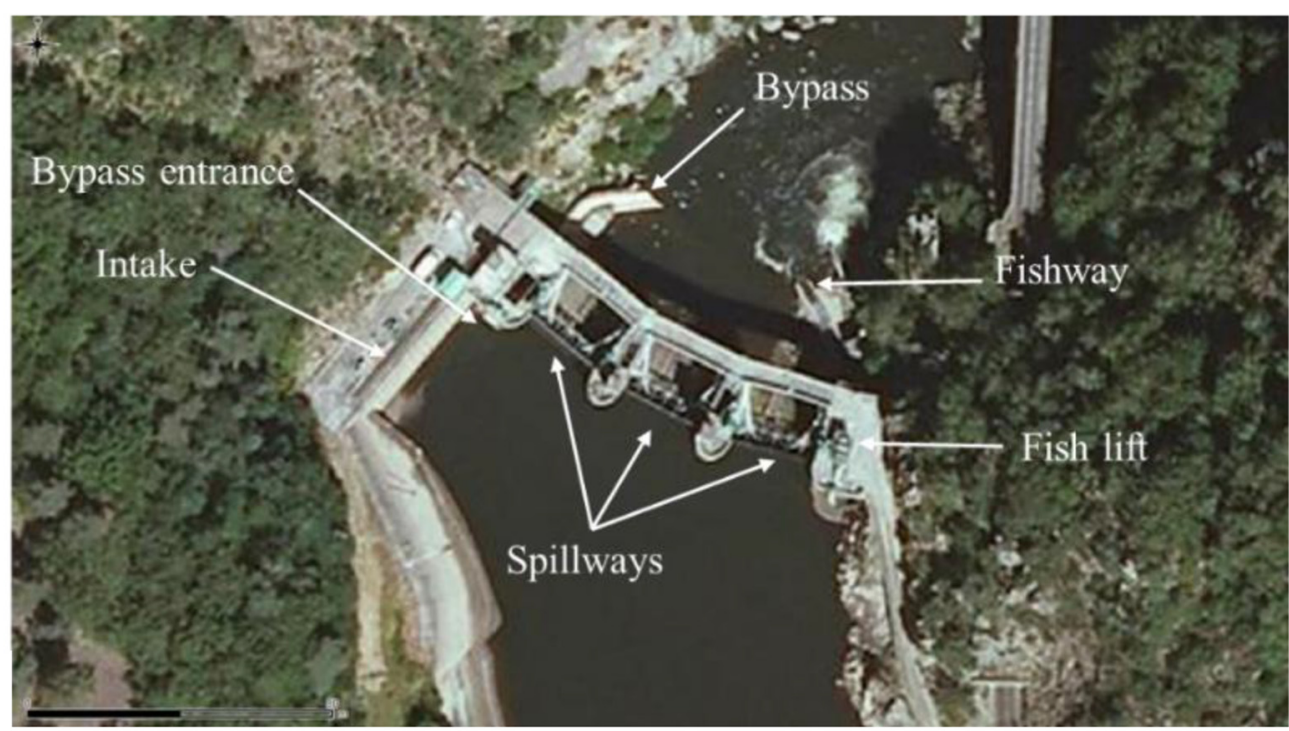

(b)
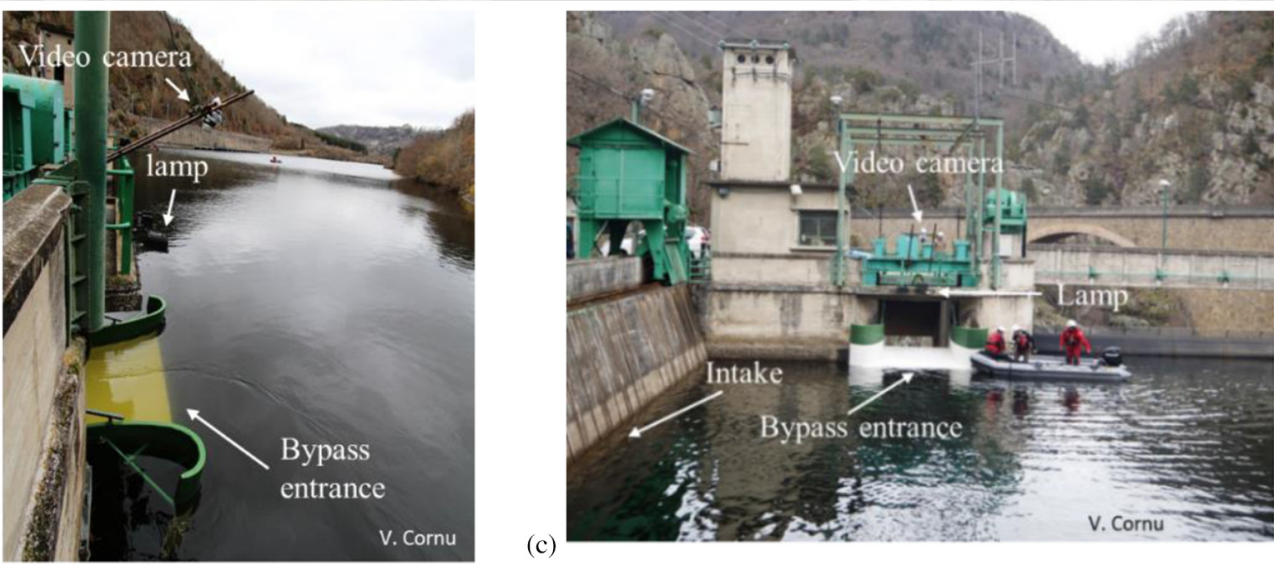

Fig. 2. Aerial view of the Poutès dam (a), side view of the bypass entrance (b) and front view of the intake and bypass entrance (c).

regulates the water level to ensure a continuous flow of $2 \mathrm{~m}^{3} \mathrm{~s}^{-1}$, representing $7.1 \%$ of the maximum turbine flow. The bypass is lit by a $50 \mathrm{~W}$ mercury vapor lamp positioned $3 \mathrm{~m}$ above the entrance to produce a halo of light of approximately $3 \mathrm{~m}$ diameter. The efficiency of this initial passage solution and the migratory delay induced by the Poutès reservoir were previously evaluated (Tétard et al., 2016a, 2019), showing passage efficiency of $66 \%$ and significant median reservoir residence time of 9.3 days (more than 23.6 days for $25 \%$ of smolts).

\subsection{Adaptive management for smolt migration}

During the 2-year experiment, three kinds of temporary measures were implemented to improve smolt migration speed while preventing turbine entrainment: (1) water level lowering, (2) bypass design, and (3) turbine modulation and/or shutdown. To be adaptive, the management rules were discussed with the stakeholders and improved during the second migration season by feedback on the successes and failures reported during the first season.

\subsubsection{First season: 2017}

In the first season, the reservoir was lowered on March 1st to $644.7 \mathrm{NGF}$ (lowering of $5.5 \mathrm{~m}$ from the normal water level of $650.2 \mathrm{NGF}$ ). This measure decreased reservoir volume by $90 \%\left(238,706 \mathrm{~m}^{3}\right.$, down from $\left.2.4 \mathrm{Mm}^{3}\right)$ and length by $70 \%$ $(1,000 \mathrm{~m}$, down from about 3,500 m) (Figs. 1 and 3). Mean water residence time in the impoundment was reduced to about 4 hours.

At this water level, the initial bypass was inoperative, and therefore a new temporary bypass entrance was designed using the left bank spillway (Fig. 3). An extension of metal uprights and wooden parts of about $1 \mathrm{~m}$ was fashioned to partly obstruct the weir crest and create a $4.5 \mathrm{~m}$-wide notch that delivered a flow of $5 \mathrm{~m}^{3} \mathrm{~s}^{-1}$ with a hydraulic head $\geq 70 \mathrm{~cm}$ over the weir crest. Unlike in normal operating conditions, the temporary bypass was not lit. To prevent abrasion injury, the facing of the spillway in front of the temporary bypass entrance was softened.

To increase passage efficiency, turbine operation was modulated during 20 nights, by implementing different decisions rules depending on river flow to maximize bypass 

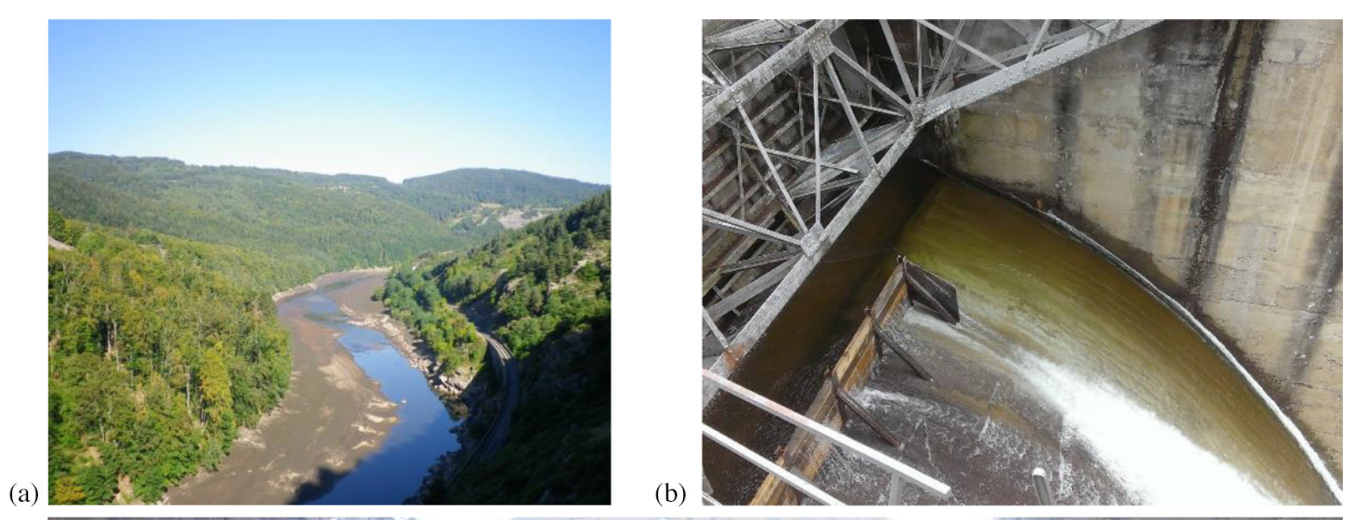

(1)

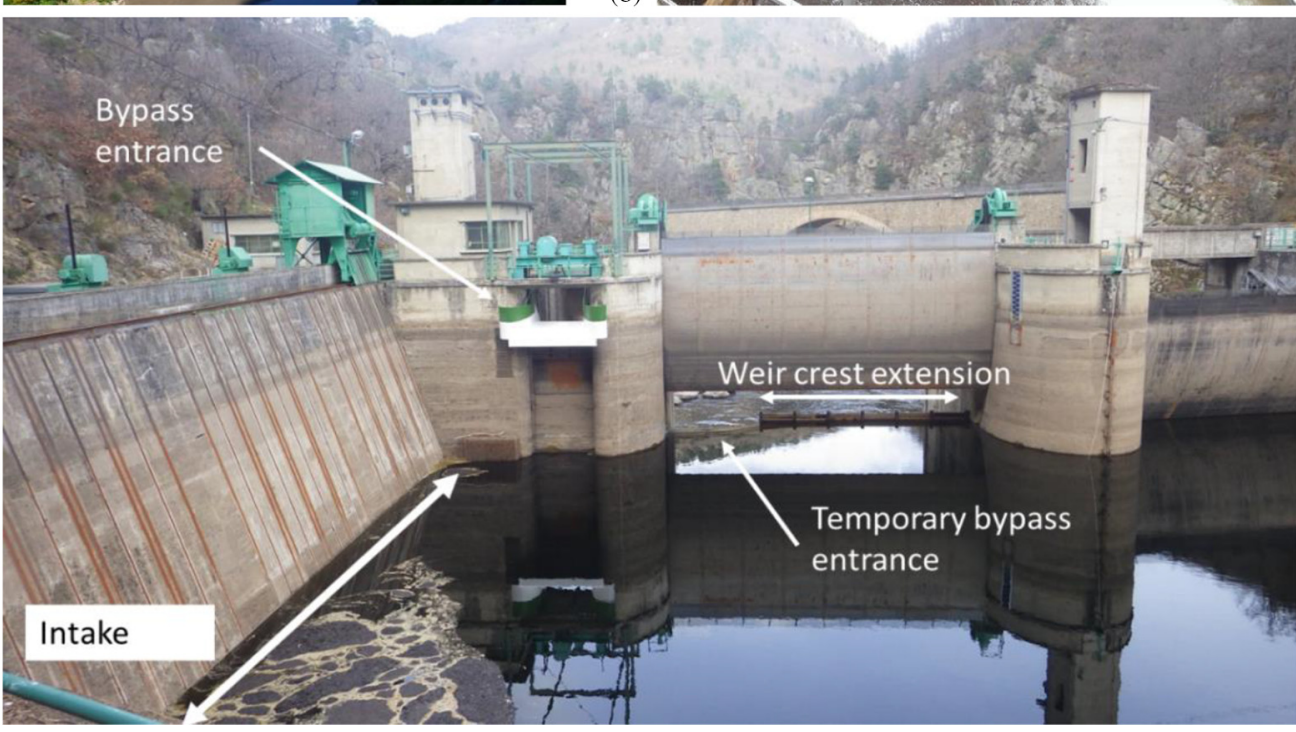

(b)

Fig. 3. Picture of upstream limit of the temporary Poutès reservoir (a). Top view of temporary bypass (b). Upstream view of intake, usual (nonfunctional) and temporary bypass entrances (c).

Table 1. Turbine management rules during temporary measures period for the 2017 season.

\begin{tabular}{lllll}
\hline River flow & \multicolumn{2}{c}{ Power plant discharge } & \multicolumn{2}{c}{ Bypass discharge } \\
\cline { 2 - 3 } & $\mathrm{m}^{3} \mathrm{~s}^{-1}$ & $\%$ & & $\mathrm{~m}^{3} \mathrm{~s}^{-1}$ \\
\hline$\leq 8 \mathrm{~m}^{3} \mathrm{~s}^{-1}$ & 0 & 0 & {$[5 ; 8]$} & 100 \\
{$\left[9 \mathrm{~m}^{3} \mathrm{~s}^{-1} ; 11 \mathrm{~m}^{3} \mathrm{~s}^{-1}\right]$} & {$[1 ; 3]$} & $11-27 \%$ & 8 & $73-89 \%$ \\
{$\left[12 \mathrm{~m}^{3} \mathrm{~s}^{-1} ; 40 \mathrm{~m}^{3} \mathrm{~s}^{-1}\right]$} & {$[4 ; 13]$} & $31-37 \%$ & {$[8 ; 27]$} & $63-69 \%$ \\
$>40 \mathrm{~m}^{3} \mathrm{~s}^{-1}$ & 28 & $\leq 70 \%$ & $\geq 12$ & $\geq 30 \%$ \\
\hline
\end{tabular}

discharge ratio, especially during low-flow periods (Tab. 1). Modulation was set to begin at night ( $7 \mathrm{pm}-7 \mathrm{am}$, local time) when migrating smolts are expected to be found. From March 1st, modulation was triggered either by smolt captures upstream of the reservoir (rotary screw trap located next to Station 1; Fig. 1) or when the river flow exceeded a threshold of $20 \mathrm{~m}^{3} \mathrm{~s}^{-1}$. The measure was continued for 20 nights and the reservoir level was raised after the last night.

\subsubsection{Second season: 2018}

During the second season, the temporary operating measures were similar to those of 2017 , but the stakeholders decided to stop turbine operations completely instead of merely modulating them. Unlike in 2017, the reservoir level was kept low for approximately 1 week after the last night, to carry out maintenance work on the intake.

\subsection{Fish catching and tagging}

Two rotary screw traps were used to catch wild migrating fish, as in previous studies conducted in this area (Tétard et al., 2016a, 2019). The first one ("Alleyras trap") was positioned about $1.5 \mathrm{~km}$ upstream of the normal Poutès reservoir, and the second ("Chanteuges trap") about $28.5 \mathrm{~km}$ downstream of the dam. The two rotary screw traps can operate until river flow 
Table 2. Characteristic of tagged smolts in 2017 and 2018. The number, origin, length, and weight of fish are provided, as well as the reservoir level at the time of release.

\begin{tabular}{|c|c|c|c|c|c|}
\hline Release date & Number & Origin & Reservoir level & Total Length (mm) & Weight $(\mathrm{g})$ \\
\hline 9th March 2017 & 1 & Wild (Alleyras trap) & Low & \multirow{3}{*}{$152 \pm 30.5$} & \multirow{3}{*}{$31.8 \pm 19.6$} \\
\hline 18th March 2017 & 1 & Wild (Alleyras trap) & Low & & \\
\hline 24th March 2017 & 8 & Wild (Alleyras trap) & Low & & \\
\hline 2nd April 2017 & 24 & Fish farm & Low & & \\
\hline 12th April 2017 & 20 & Fish farm & High & $164 \pm 9.7$ & $40.4 \pm 7.4$ \\
\hline 8th March 2018 & 25 & Wild (Chanteuges trap) & Low & $147.4 \pm 15.4$ & $26.7 \pm 8.5$ \\
\hline 30th March 2018 & 45 & Fish farm & Low & $168.5 \pm 7.3$ & $41.8 \pm 6.1$ \\
\hline
\end{tabular}

reaches a maximum of around $30 \mathrm{~m}^{3} \mathrm{~s}^{-1}$ and $50 \mathrm{~m}^{3} \mathrm{~s}^{-1}$ for Alleyras and Chanteuges, respectively (CNSS, 2013, 2014). In 2017, the Alleyras trap operated from February 27th to April 10th, and the Chanteuges trap from February 28th to May 31st, and in 2018 from March 3rd to April 12th and from March 1st to May 13th, respectively.

Overall, smolts collected in the Alleyras trap were preferred, to limit fish transport over a long distance (about $30 \mathrm{~km}$ from the release site). However, as the number of fish trapped at Alleyras was insufficient, some smolts collected in the Chanteuges trap and some from the National Wild Salmon Conservatory (CNSS) fish farm were used to ensure that a substantial number of fish were tagged, whatever the hydrological conditions (e.g., floods) (Tab. 2).

Traps were checked every morning during the experiment and fish were tagged and released in the evening. Before tagging, fish were anaesthetized in phenoxyethanol solution at $0.3 \mathrm{ml} . \mathrm{I}^{-1}$, then measured (TL, mm) and weighed $(\mathrm{TW}, \mathrm{g})$. Acoustic tags were then carefully inserted into the body cavity via a lateral incision. Closure used surgical glue. Conventional ethical standards for the care and use of animals were followed. JSAT L-AMT-1.421 tags $\left(10.5 \times 5.2 \mathrm{~mm}\right.$ wide; $416.7 \mathrm{kHz}$; Lotek Wireless Inc. $\left.{ }^{\circledR}\right)$ were used, weighing $0.32 \mathrm{~g}$ in air. Transmitters were programmed to emit a unique individually recognizable coded acoustic signal every 5 seconds, resulting in a battery life of approximately 40 days. Weight in air amounted to less than $2 \%$ of fish body weight, as recommended by Winter (1996). After recovering from the anesthesia, fish were released $3 \mathrm{~km}$ upstream of the reservoir. As capture could occur late in the temporary operating measure period and smolts could delay their migration, they were also tracked under high reservoir level conditions.

\subsection{Telemetry array and position calculation}

Smolt movements throughout the study area were tracked in 2D using acoustic telemetry. 23 and 16 WHS4000 hydrophones (Lotek Wireless Inc. ${ }^{\circledR}$ ) were installed in 2017 and 2018, respectively. Hydrophones were positioned at 5 stations in 2017 and only 4 stations in 2018 (installation limitations). Stations were distributed from upstream to downstream to assess smolt progression within river reaches (Fig. 1).

- Station 1 (3 km from release site, 4 hydrophones) was located upstream and detected smolts in the free-flowing
Allier River (about $1.5 \mathrm{~km}$ from the normal upstream limit of the Poutès reservoir).

- Station 2 (6.9 km from release site, 4 hydrophones in 2017, but not equipped in 2018) was located at the temporary upstream limit of the Poutès reservoir (about $700 \mathrm{~m}$ upstream of the dam).

- Station 3 (7.6 km from release site, 7 hydrophones in 2017 and 4 in 2018) was located in the dam zone and was used to track fish movement up to approximately $80 \mathrm{~m}$ upstream of the dam.

- Station 4 (7.9 km from release site, 4 hydrophones) was located $300 \mathrm{~m}$ downstream of the dam, in the bypass stretch, to confirm bypass passages.

- Station 5 (21.6 km from release site, 4 hydrophones) was located in the free-flowing Allier River, $4 \mathrm{~km}$ downstream of the confluence between the bypass stretch and the tailrace of the powerhouse.

Hydrophones were positioned on $1 \mathrm{~m}$ PVC tubes anchored on $25 \mathrm{~kg}$ concrete bases and their GPS location (precision: $0.3 \mathrm{~m}$ ) was recorded with a differential GPS (Leica $\left.{ }^{(\mathbb{R}}\right)$. The 2D position was calculated using UMAP V1.3.1 (Lotek Wireless Inc. ${ }^{\circledR}$ ) and was post-processed using 0.3 DOP (Dilution of Precision, UMAP parameter) (Tétard et al., 2019).

In 2017, a preliminary survey was conducted in station 3 to assess positioning error (i.e., Euclidian distance between calculated and actual positions of the tag) (Roy et al., 2014). It was conducted on a boat along two trajectories, using a differential GPS device. Median positioning error was $0.7 \mathrm{~m}$.

\subsection{Behavioral metrics and data analysis}

\subsubsection{Residence time in the reservoir}

To assess potential migration delay, residence time in the reservoir was calculated as the time difference between $1 \mathrm{st}$ detection in the reservoir (station 2) and last detection in the dam zone (station 3). At high reservoir level, the upstream limit of the reservoir was not equipped with hydrophones (Fig. 1), and reservoir entry time was estimated by adding 2.4 hours to the last detection in station 1 . This value corresponds to the median travel time between station 1 and the reservoir at high level, as estimated in a previous study (Tétard et al., 2016b). In 2018, the station 2 was not equipped with hydrophones because of installation issues. Therefore, the median travel time between station 1 and station 2 (72 $\mathrm{min})$ 
calculated in 2017 was used to estimate reservoir entry time. Afterwards, the effect of reservoir level, flow conditions and fish origin on residence time was analyzed using an ANOVA after log-transformation of raw data to normalize the distribution of residuals. Linear regression assumptions were checked.

\subsubsection{Attempt and passage at the dam}

Attempted passage in the dam zone and back-and-forth movements in the temporary reservoir were computed (backand-forth movements could only be computed in 2017, when station 2 was operational) for each tagged smolt. For a given individual, successive attempted passages were distinguished by considering a minimal time threshold of $30 \mathrm{~min}$ between two consecutive detections (Tétard et al., 2019). The MannWhitney test was used to compare number of attempts per smolt between low and high reservoir level.

Successful passages were confirmed when a fish was detected in the bypass stretch downstream of the dam, without crossing turbines. However, some smolts which used the bypass were overlooked in the bypass stretch during high flow periods. In such cases, 2D trajectories in the forebay were used, when possible, to adjust passage rates. When a precise trajectory leading to spillways or bypass was observed, the fish was assigned to the bypass stretch. When the trajectory remained undefined, the fish was considered to have potentially crossed the turbines. Accordingly, passage estimates are conservative, with unknown route considered as a turbine route.

Time of passage was defined as the time of the fish's last position in the forebay before passage. Passage period (twilight or night) was also recorded, according to the angle between the center of the sun and the horizon (when the geometric center of the sun reached $-6^{\circ}$ and $-18^{\circ}$ below the horizon, for civil and astronomical twilights, respectively).

Finally, the spatial behavior of smolts in the dam zone was investigated, based on UD (utilization distribution), calculated on the kernel method (Silverman, 1986, Calenge, 2011) according to reservoir level. This approach was only conducted in 2017, because the smaller number of hydrophones in 2018 prevented accurate location of smolts.

\subsubsection{Passage efficiency and transfer rates between stations}

Transfer rate between stations was defined as the number of fish detected in a given station proportionally to the previous station. As turbine management differed between the two years, transfer rates were calculated per year. To take account of smolt overlooked during high flow, transfer rates were adjusted by adding detections when individuals were detected in downstream stations: for instance, a fish detected at station 4 had necessarily passed stations 1,2 and 3 . For station 5 , the transfer rate was calculated by considering only fish that had been detected in station 4 , and thus had not crossed the power plant; thus, the transfer rate was reduced, as smolt missed in station 4 but detected in station 5 were not included. Passage efficiency at the dam was calculated as the number of successful passages (detected in station 4 or using trajectory) proportionally to the number of fish detected in station 3 .
To explore whether the temporary measures influenced passage efficiency, potential differences between low and high reservoir levels were compared on $\chi^{2}$ test.

\subsubsection{Comparison of temporary measures}

Some fish were tagged and released throughout the study period, and passages, transfer rates and residence times were compared according to reservoir level (high versus low) and flow conditions (high versus low) during smolt passage. Initiated from March 1st each year, the low reservoir level period ended on April 7th at 8 pm UTC in 2017 and on April 9th at $11 \mathrm{pm}$ UTC in 2018. High and low river flow periods were dichotomized according to a $30 \mathrm{~m}^{3} \mathrm{~s}^{-1}$ threshold, which is approximately twice the mean inter-annual flow. This threshold allowed: 1) results to be examined when detection efficiency was high in the bypass stretch (fewer missed detections), and 2) the impact of river flow on residence time and transfer rates between stations to be minimized (smolts were expected to show greater migration speed and greater probability of bypass/spillway passage in high flow periods).

All statistical tests were performed using $\mathrm{R}$ software (R Development Core Team 2018), implemented with the MASS, maptools, sp, raster, adehabitatHR and rgdal packages.

\section{Results}

\subsection{Management measures and migration dynamics}

\subsubsection{First season}

The reservoir level was lowered on March 1st and began to rise on April 7th, reaching its normal level on April 11th. Turbine modulation was implemented from March 4th, when river flow was $20 \mathrm{~m}^{3} \mathrm{~s}^{-1}$, to March 16 th, when the local monitoring committee decided to suspend temporary measures until more favorable environmental conditions were met (8 "modulation nights" left). (Fig. 4). On March 24th, a second flood quickly raised the river flow, which reached $108 \mathrm{~m}^{3} \mathrm{~s}^{-1}$ on March 25th, resulting in turbine operation modulation being stopped. After the flood, modulation was reiterated for 8 nights until April 7th: i.e., 20 nights over the season (Fig. 4).

During the first season, 54 smolts were tagged and released between March 9th and April 12th 2017 (Tab. 2). Only 10 wild smolts were caught and tagged on March 9th, 18th and 24th. The rotary screw traps were inoperable after this date because of the high river flow. Accordingly, hatchery smolts from the fish farm were used for tracking, because environmental conditions (flood, temperature between $6.5^{\circ}$ and $9^{\circ} \mathrm{C}$ ) and smolt abundance in the trap on March 24th suggested the beginning of an important migration episode. A total of 44 hatchery smolts were thus tagged and released on April 2nd at low reservoir level (24 individuals) and on April 12th at high reservoir level (20 individuals). No significant differences between wild and hatchery smolts were reported, either in total length (Mann-Whitney, $p=0.09$ ) or in weight ( $t$-test, $p=0.2$ ).

Overall, the migration pattern differed between periods of low and high reservoir level (Fig. 4). When reservoir level was low, passage dynamics tended to be similar to that observed upstream of the temporary reservoir (station 1), suggesting that smolts rapidly crossed the dam to reach downstream reaches. Cumulative percentage of passages was usually higher than the 

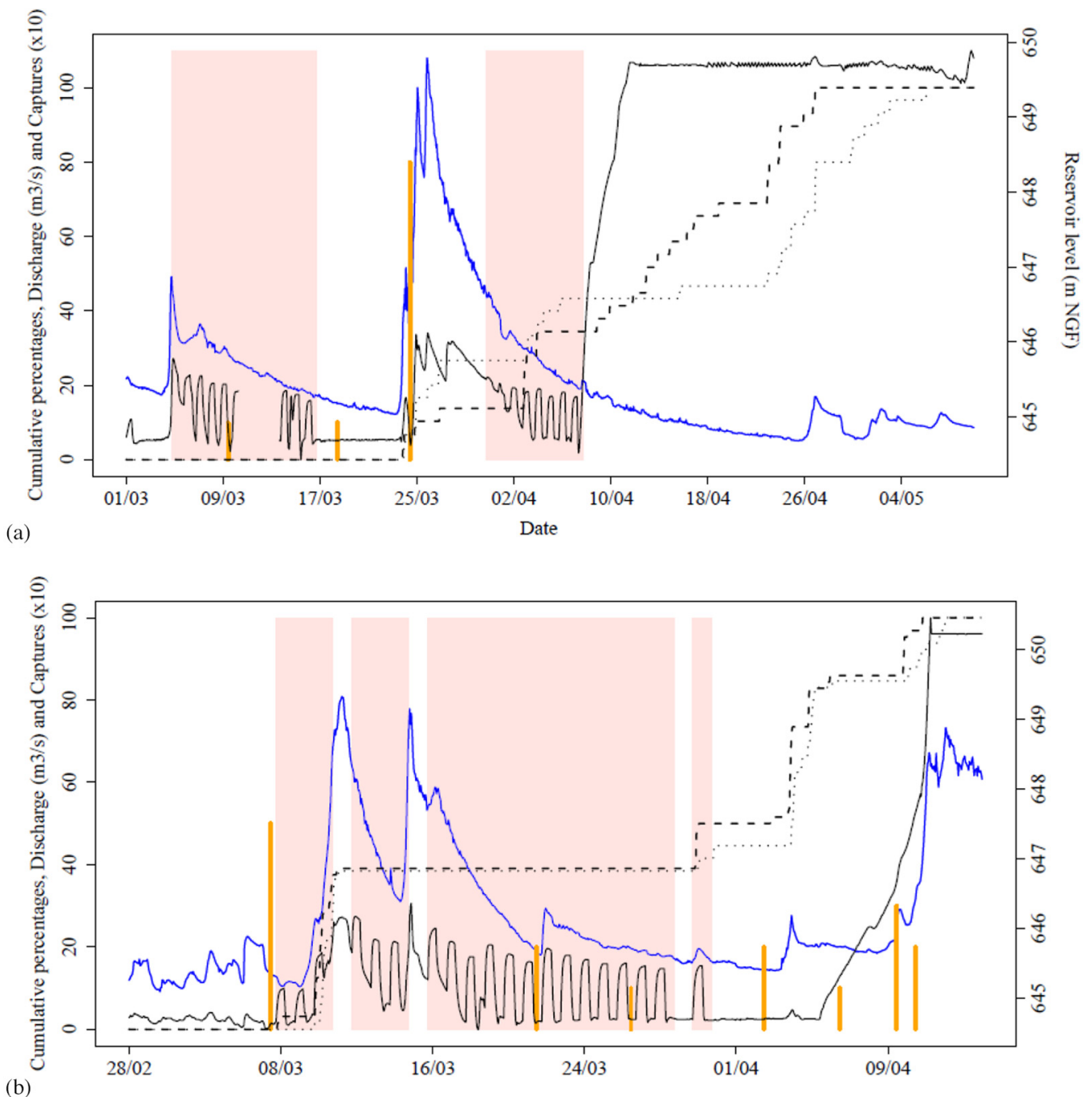

Fig. 4. Changes in hourly river flow (blue), reservoir level (black) and captures at the Alleyras trap (x10, orange) during the study period in 2017 (a) and 2018 (b). The periods of turbine operation modulation are indicated (red rectangle). Cumulative percentages of smolts detected in Station 1 (thick dashed line) and passing the Poutès dam (dotted) are also indicated

percentage of detection in station 1 , because of individuals undetected during the flood. After raising the reservoir level, cumulative detections in station 1 greatly increased (from $35 \%$ to $69 \%$ between April 8th and April 18th), but the percentage of passages remained much lower (Fig. 4). This observation suggests that smolts continued to enter the reservoir but did not manage to exit it.

\subsubsection{Second season}

The reservoir level was lowered on March 1st and remained low until April 9th. Turbine shutdown was implemented from March 8th, when the first smolts $(N=8)$ were caught in the rotary screw trap, to March 11th, when the flood occurred and turbines were restarted to protect the temporary bypass. Turbines were then stopped from March 12th to March 15th, when a second flood quickly raised river flow to $75 \mathrm{~m}^{3} \mathrm{~s}^{-1}$. Thereafter, the turbines were stopped every night from March 16th to 29th (13 nights) (Fig. 4). It is important to note that turbine shutdown duration changed during the temporary operating measures period, lasting 2 hours less (from 7pm to 5am local time) until March 20th and then prolonged to the planned time slot of $7 \mathrm{pm}$ to $7 \mathrm{am}$.

25 wild smolts from the Chanteuges trap were tagged and released on March 8th (Tab. 2). The traps could not operate during the two flood episodes. From March 19th to March 29th, although environmental conditions looked quite favorable for smolt migration, no significant captures were made. As smolt stocks upstream of Poutès were quite low and it was presumed that a large majority had migrated during the two flood episodes ( 5 smolts caught at the beginning of the first episode), it was decided to tag hatchery smolts to track them during the last remaining night of turbine shutdown. 45 hatchery smolts were tagged and released on March 30th when the turbines had been stopped for the last night (Tab. 2). Wild smolts were smaller ( $t$-test, $P<0.001)$ and lighter (MannWhitney, $P<0.001)$ than the hatchery smolts.

At low reservoir level, migration dynamics was very similar in stations 1 and 3. All fish of the first release $(N=25)$ migrated during the first flood, and especially during the night 
S. Tétard et al.: Knowl. Manag. Aquat. Ecosyst. 2021, 422, 4

Table 3. Number of smolts and transfer rates between stations in 2017 and 2018 . The results are provided for all tagged fish (global) and depending on the local conditions (reservoir level and river flow) when smolts entered in the Poutès reservoir.

\begin{tabular}{|c|c|c|c|c|c|c|c|}
\hline & & Release site & Station 1 & Station 2 & Station 3 & Station 4 & Station 5 \\
\hline \multirow{15}{*}{$\begin{array}{l}\text { Number of smolts } \\
\text { (transfer rate\%) }\end{array}$} & \multicolumn{7}{|c|}{ Global } \\
\hline & 2017 & $54(/)$ & $34(63 \%)$ & $33(97 \%)$ & $32(97 \%)$ & $20(63 \%)$ & $15(75 \%)$ \\
\hline & 2018 & $70(/)$ & $67(96 \%)$ & / & $65(97 \%)$ & $43(66 \%)$ & $28(65 \%)$ \\
\hline & \multicolumn{7}{|c|}{ Low reservoir level } \\
\hline & 2017 & & $14(/)$ & $14(100 \%)$ & $14(100 \%)$ & $7(50 \%)$ & $4(57 \%)$ \\
\hline & 2018 & & $57(/)$ & 1 & $55(95 \%)$ & $38(69 \%)$ & $25(66 \%)$ \\
\hline & \multicolumn{7}{|c|}{ Low reservoir level and river flow $\leq 30 \mathrm{~m}^{3} \mathrm{~s}^{-1}$} \\
\hline & 2017 & & $6(\overline{)}$ & $6(100 \%)$ & $6(100 \%)$ & $3(60 \% *)$ & $2(67 \%)$ \\
\hline & 2018 & & $36(/)$ & / & $33(92 \%)$ & $23(70 \%)$ & $15(65 \%)$ \\
\hline & \multicolumn{7}{|c|}{ High reservoir level } \\
\hline & 2017 & & $20(/)$ & $19(95 \%)$ & $18(100 \%)$ & $13(72 \%)$ & $11(85 \%)$ \\
\hline & 2018 & & $10(/)$ & 1 & $10(100 \%)$ & $5(50 \%)$ & $3(60 \%)$ \\
\hline & \multicolumn{7}{|c|}{ High reservoir level and river flow $\leq 30 \mathrm{~m}^{3} \mathrm{~s}^{-1}$} \\
\hline & 2017 & & $20(/)$ & $19(95 \%)$ & $18(100 \%)$ & $13(72 \%)$ & $11(85 \%)$ \\
\hline & 2018 & & $2(/)$ & 1 & $2(100 \%)$ & $0(0 \%)$ & 1 \\
\hline
\end{tabular}

* One smolt was detected in station 3 but did not approach the dam.
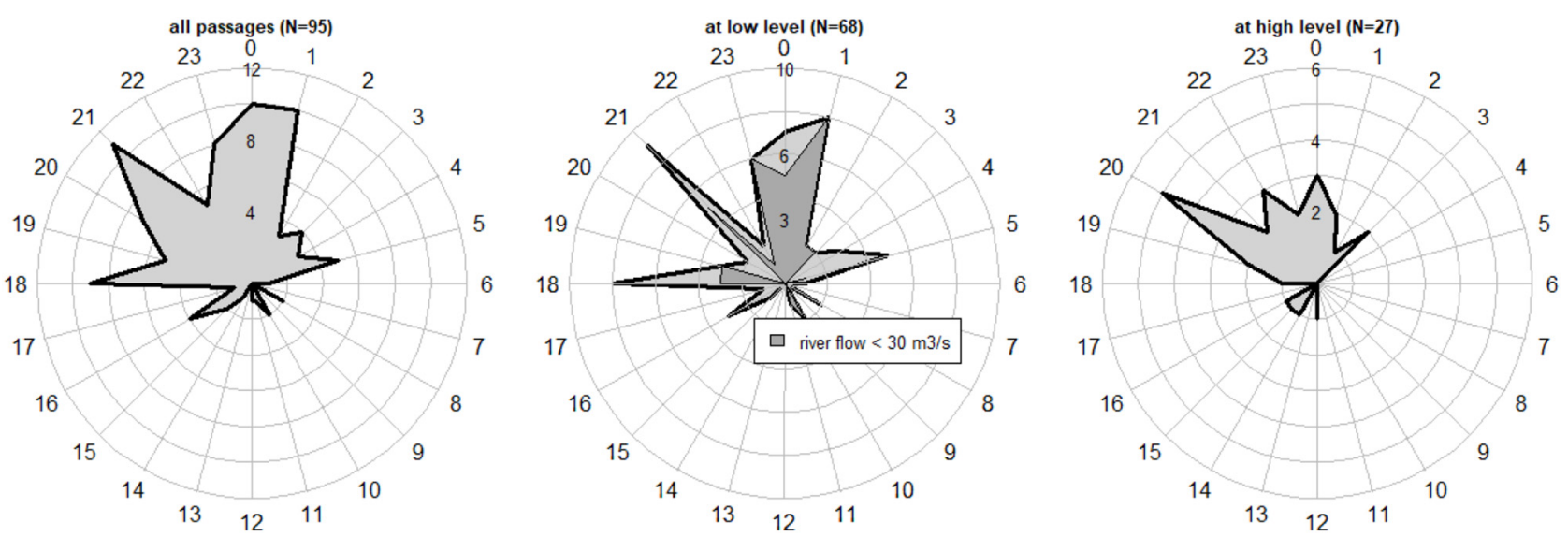

Fig. 5. Radial plots of passages times (UTC) at Poutès according to reservoir level in 2017 and 2018.

of March 11-12th, explaining why only 4 smolts passed the dam when the turbines were stopped. Logically, no movement happened until second release. A majority of detected smolts of the 2nd release (38/42) waited for several days and arrived in Poutès during an increase in river flow on April 4-5th and the flood on April 10-14th. Consequently, only 2 smolts of the 2nd release passed Poutès when the turbines were stopped. Arrivals in station 1 and passages at the dam were slightly dissociated in the last part of the reservoir level raising period (from April 10th to April 13th), although the phenomenon was less pronounced than in 2017.

\subsection{Transfer rate, passage efficiency and passage time}

During the study, $63 \%$ and $96 \%$ of smolts were detected in 2017 and 2018, respectively. Overall, transfer rates from station 1 to the dam (station 3 ) were very high in both years, at $94-97 \%$ (Tab. 3). However, passage efficiencies were $63 \%$ in 2017 and $66 \%$ in 2018 . Transfer rates to station 5 were $75 \%$ (2017) and 65\% (2018).

In the two years, transfer rates to the station 4 $\left(\chi_{2017}^{2}=0.36, p_{2017}=0.85 ; \quad \chi_{2018}^{2}=0.80, p_{2018}=0.37\right)$ did not significantly differ between low and high reservoir levels, indicating that this management measure did not affected the proportion of smolts passing the dam. Similar results were obtained at low river flow, which underlined the constancy of results according to detection efficiency.

The 95 smolt passages (independently of migration route) essentially occurred during twilight or at night, with $81.2 \%$ between $6 \mathrm{pm}$ and $2 \mathrm{am}$ (Fig. 5). However, the proportion of smolts migrating during daytime and twilight was higher when river flow was $\geq 30 \mathrm{~m}^{3} \mathrm{~s}^{-1}$ (Fig. $6, \chi^{2}=11, p<0.01$ ) at low reservoir level. 

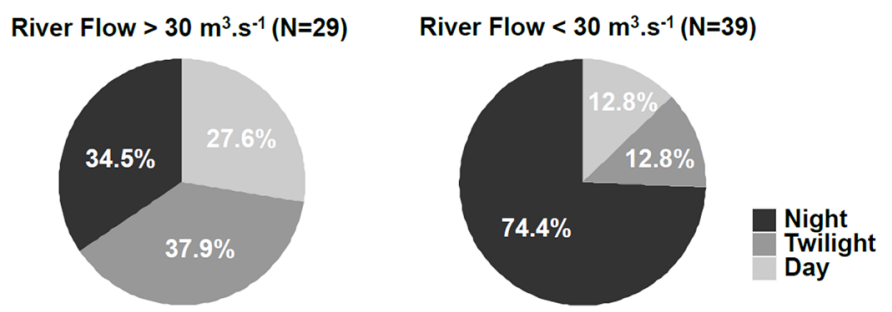

Fig. 6. Distribution of passage periods according to river flow at low reservoir level.

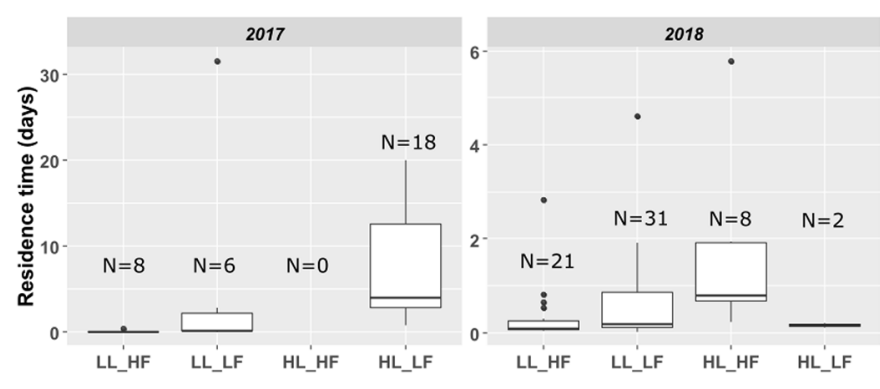

Fig. 7. Residence time according to reservoir level and river flow during smolt entry in 2017 (left) and 2018 (right). LL and HL: low and high level, respectively. LF and HF: low and high flow, respectively. Note that the scale of y-axis differs between the 2 graphs.

Table 4. Analysis of variance table on log-transformed residence time.

\begin{tabular}{lllll}
\hline & Df & Sum Sq & $F$ value & $p(>F)$ \\
\hline Reservoir level & 1 & 133.65 & 64.99 & $p<0.001$ \\
River flow & 1 & 23.57 & 11.46 & $p<0.01$ \\
Reservoir level: River flow & 1 & 0.04 & 0.02 & 0.89 \\
Fish origin & 1 & 0.26 & 0.13 & 0.72 \\
Total length & 1 & 0 & 0 & 0.1 \\
Residuals & 89 & 2.03 & & \\
\hline
\end{tabular}

\subsection{Residence time and behavior in the reservoir}

\subsubsection{Residence time}

At low reservoir level, median residence time was $50.8 \mathrm{~min}$ in 2017 and $2.1 \mathrm{~h}$ in 2018 at high river flow, and slightly longer at low river flow (3.6 h in 2017 and $4.4 \mathrm{~h}$ in 2018; Fig. 7). At high reservoir level, the time spent by smolts in the reservoir was substantially longer, at a median 4 days in 2017 at low river flow (no smolts entered the reservoir at high river flow in 2017). In 2018, median residence times at high reservoir level were $19.1 \mathrm{~h}$ and $4.4 \mathrm{~h}$ at high and low river flow, respectively. Linear model on log-transformed data showed that reservoir level (ANOVA, $F=64.99, p<0.001$ ) and flow conditions (ANOVA, $F=11.46, p<0.01$ ) were the only variables that significantly influenced the residence time (Tab. 4).

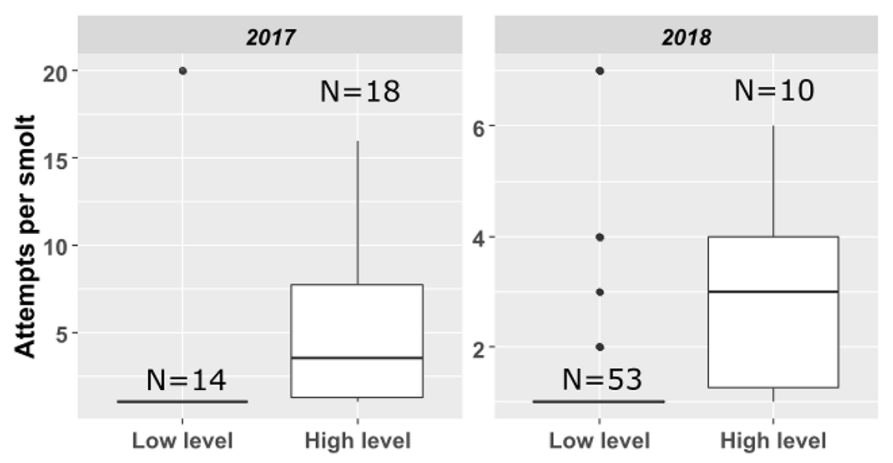

Fig. 8. Number of passage attempts per smolt according to reservoir level in 2017 (left) and 2018 (right). Note that the scale of y-axis differs between the 2 graphs.

\subsubsection{Attempts to pass}

At low reservoir level, $93 \%$ and $87 \%$ of smolts passed the dam at the first attempt, in 2017 and 2018, respectively (Fig. 8). At high reservoir level, the median number of attempts per smolt was 3.5 (range, 1-16) in 2017 and 3 (range, 1-6) in 2018. The difference in number of attempts between low and high levels was significant in both years (2017: $W=50.5$, $p<0.01$; 2018: $W=115, p<0.001)$.

In 2017, UD maps revealed that detection density peaked in the north-west corner of hydrophone array (Fig. 9). Despite the DOP filter, a few positions lay outside reservoir boundary. At low reservoir level, the probability distribution of smolt relocation was quite concentrated, forming a "channel" directed toward the bypass. The maximum probability density was located just upstream of the bypass, at approximately 11 to 29 meters from the bypass entrance. In contrast, relocations were distributed over the whole dam area at high reservoir level.

\section{Discussion}

Numerous studies reported migration delay due to hydropower reservoirs and/or tested the efficiency of various fish passage solutions (Tomanova et al., 2018; Schwinn et al., 2019). To our knowledge, our study is the first to assess the impact of temporary measures aiming both to improve passage efficiency and reduce migration delay, with targeted turbine operations and reservoir level lowering.

The study confirmed that lowering the reservoir level and reducing mean water residence time from 1.67 days to 4 hours was a very effective means of reducing the migration delay caused by the reservoir. In 2017, when river flow was less than twice the mean annual flow, operating at low level reduced median residence time from 4 days to 3.6 hours. In low-flow conditions, median residence time at high reservoir level as evaluated in 2015 was 9.3 days (Tétard et al., 2016a). River flow had an important impact whatever the reservoir level, and explained the great difference in residence time between 2017 (mean river flow $=9.6 \mathrm{~m}^{3} \mathrm{~s}^{-1}$ ) and 2018 (mean river flow $\left.=49.4 \mathrm{~m}^{3} \mathrm{~s}^{-1}\right)$. The causes of the substantial migration delay at high reservoir level were identified in 2015 
UD (low reservoir level)

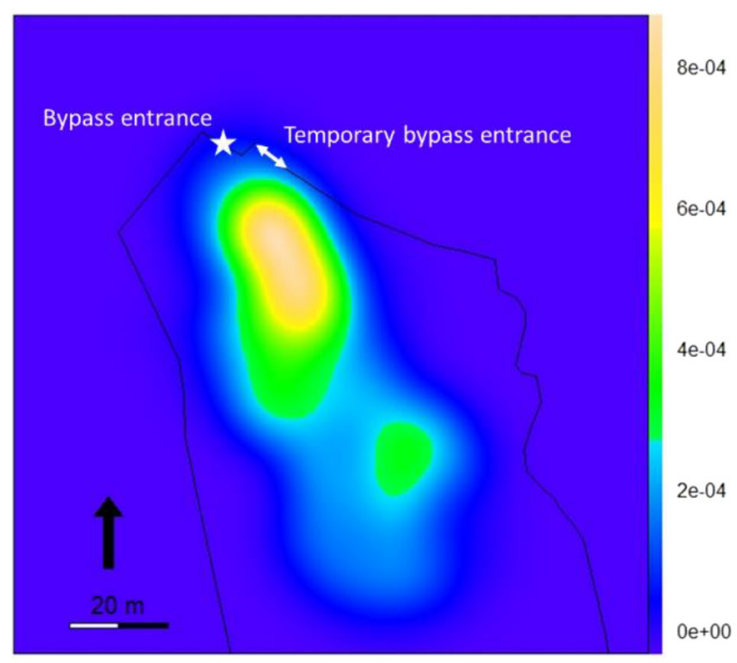

UD (high reservoir level)

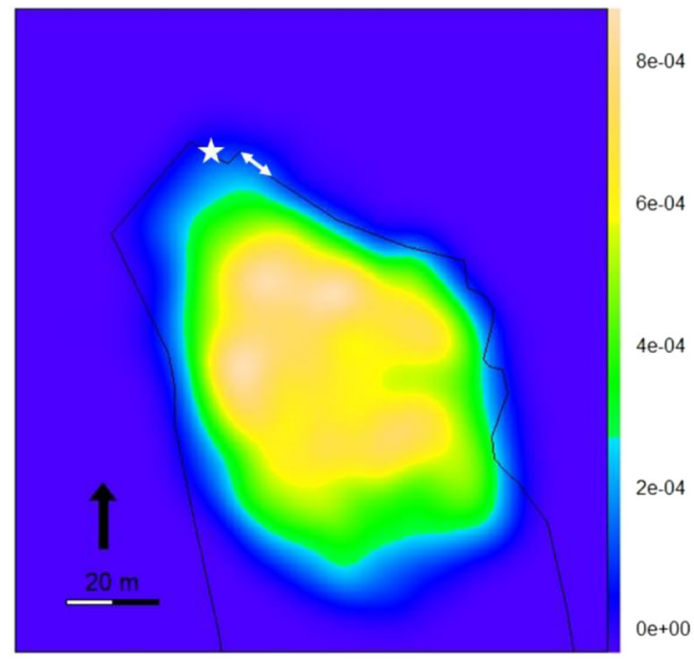

Fig. 9. Probability density of smolt relocation (UD) according to reservoir level in 2017.

as reluctance to enter the bypass and disorientation in the reservoir (Tétard et al., 2016a). Accordingly, the median number of passage attempts in the dam zone before passing downstream was 12 , and $64.8 \%$ of smolts went back to the upstream end of the reservoir at least once after being detected in the dam area (Tétard et al., 2016a). In contrast, when the reservoir was lowered, no fish went back upstream, and they crossed the dam at the first attempt. Whichever route smolts use, they quickly crossed the reservoir and passed downstream. Although reservoir level modulation appears efficient to mitigate impact on smolt migration, our study did not consider the influence on other biological components, such as benthic fauna or riparian vegetation. Further investigations should thus consider monitoring a larger range of taxa to preserve the functional roles of water reservoir.

To explore whether the temporary reservoir still induced migration delay, the time needed by smolts to travel the same distance was compared with migration speed in a free-flowing stretch. Over a distance of $3.9 \mathrm{~km}$ from station 1 to station 2 (at low reservoir level: Fig. 1), median migration speed was $20 \mathrm{~km} . \mathrm{d}^{-1}$. This was comparable to other reports, although migration speed is known to vary between rivers and environmental conditions (Imbert et al., 2013; Havn et al., 2018; Huusko et al., 2018). Extrapolating this speed to the temporary reservoir length (from station 2 to station 3: $700 \mathrm{~m}$ ) would imply $50.4 \mathrm{~min}$ to cross the reach (against $4.4 \mathrm{~h}$ calculated in the study). Despite uncertainty in estimation, this shows that the temporary reservoir would still induce delay, however short, probably linked to velocity field decrease in the reservoir. One interesting question remains: transition from a situation with substantial delay to an acceptable situation for smolt migration is probably progressive, but how are acceptable hydraulic conditions that prevent detrimental delay to be determined? Studies conducted at Poutès between 2015 and 2018 showed that residence time was more or less of the same order as the mean water residence time. This is essential information for stakeholders discussing remedial measures in other situations.
Results for passage efficiency were less clear. At low reservoir level, average passage efficiency was $65 \%$, whereas it ranged between $50 \%$ and $72 \%$ at high level between 2015 and 2018 (Tétard et al., 2019). Although it is quite similar regardless of reservoir level, this results from different situations. At high reservoir level, a substantial proportion of smolts come to the dam but never cross it. These smolts are thus liable to be predated in the reservoir or "desmoltify". In this configuration, focusing only on smolts that pass the dam by whichever route (bypass, spillways or intake), the proportion of smolts using the bypass at high reservoir level was calculated in a radiotracking study in 2004 as close to $90 \%$ (Bach et al., 2004). At low reservoir level, almost all smolts detected at the dam passed it, indicating that a higher proportion was led into the intake and hydropower turbines. This seems obvious, as the intake is $7 \mathrm{~m}$ below the surface at normal reservoir level but only $1.5 \mathrm{~m}$ at low level. Nevertheless, modulating turbine operations should have reduced the risk by reducing the attractiveness of the intake. Due to the high hydrological conditions during the two years of the study, spill ratio (Q spill/Q total) during passage at low reservoir level was substantial, at $20-74 \%$ in 2017 . This shows that spilling water to divert smolts is not enough if the gap-width of the rack is not sufficiently repulsive, especially when the hydropower plant is approaching maximum capacity. Haraldstad et al. (2018) showed that river flow negatively affected fish guidance efficiency in plants with rack gap-width between 50 and $80 \mathrm{~mm}$. High $(>90 \%)$ fish guidance efficiency was obtained, but only with river flow $\leq 30 \%$ of maximum plant capacity. Moreover, the geometry of the intake and resulting approach flow patterns are undoubtedly of great importance: in the case of Poutès, they may guide smolts toward the intake. Smolts typically follow bulk flow (Coutant and Whitney, 2000) and, even with high spill, it may still guide them toward the intake. This result underlines the importance of (1) stopping fish, (2) guiding them toward bypasses and (3) safely transferring them downstream, and gives credence to design criteria developed for "fish-friendly" intakes 
(Courret and Larinier, 2008; Calles et al., 2013; Nyqvist et al., 2018; Tomanova et al., 2018).

As it was concluded that modulation did not improve passage efficiency (compared to that of 2015) after the 2017 experiment, it was decided, in coordination with local stakeholders, to stop the turbines entirely with the same 20 -night quota. This strategy did not achieve the expected results on tagged smolts either, due to diurnal migration and turbine restarting during floods.

To be effective, shutdown periods must take account of smolt presence in the vicinity of the dam, in terms both of daily time slots for shutdowns (if turbines are to be restarted) and of numbers of days of shutdown. At low reservoir level, passage times suggested that a time slot from $6 \mathrm{pm}$ to $6 \mathrm{am}$ UTC would have protected $84 \%$ of smolts with turbine shutdown every night of the migration period, and $91 \%$ with a $4 \mathrm{pm}-8 \mathrm{am}$ time slot. This measure would have resulted in $97 \%$ global survival (or $98.5 \%$ with a $4 \mathrm{pm}-8 \mathrm{am}$ time slot) for $65 \%$ passage success (see results above) and 50\% turbine mortality for smolts arriving outside the shutdown time slot (Larinier and Dartiguelongue, 1989). Accordingly, thanks to the predominantly nocturnal behavior of smolts in Poutès, shutdowns targeting twilight and nights should show good efficiency. However, an important consideration to be kept in mind is that the Poutès dam is located $861 \mathrm{~km}$ from the sea, and the smolt downstream migration period begins early and is mainly nocturnal (Tétard et al., 2019). Presence of migrating smolts in the front of an obstacle and the duration of their period of migration depend on local context: e.g., environmental conditions triggering and driving migration, location of juvenile habitats according to dam location, etc. However, $40 \%$ of the smolts of the first release in $2018(10 / 25)$ migrated between $6 \mathrm{am}$ and $6 \mathrm{pm}$. During the first flood peak, after river flow reached $30 \mathrm{~m}^{3} \mathrm{~s}^{-1}, 38 \%$ of smolts migrated during daytime (8/21), with mean river flow $57 \mathrm{~m}^{3} \mathrm{~s}^{-1}$ (for 5 of them, $\left.\geq 66 \mathrm{~m}^{3} \mathrm{~s}^{-1}\right)$. These results indicated that a substantial proportion of smolts can migrate during daytime and twilight during floods, even in locations where smolts are supposedly mainly nocturnal. Consequently, negotiations to set the appropriate shutdown time slot should: (1) carefully consider the presence periods of smolts, either by analyzing biological data when available or with reference to similar contexts (time slots can focus on twilight and night at the beginning then extend over day later in the migration period) and (2) keep a flexible approach, possibly stopping turbines during the day at the beginning of the migration period when floods occur.

The second important item of the negotiation is the shutdown quota to set appropriate measures. When available, phenological models can accurately predict the phenology of smolt migration (Teichert et al., 2020a) and therefore be used to set shutdown quotas. Otherwise, the smolts' migration phenology in several similar contexts can be examined and the quota set in a conservative manner. Finally, the negotiation process will have to find a compromise according to the global survival target set by environmental authorities. The shutdown quota to reach this target will depend on the passage success rate outside of the shutdown period: the greater the success, the fewer shutdown days are needed.

Acknowledgments. The European Union financially supported the study through its Horizon 2020 AMBER project
(Grant Agreement \#689682). We thank the technical team of EDF R\&D for their contribution to the deployment phase. We also thank the CNSS team for their help during catching and tagging sessions. Special thanks to the regional Auvergne Rhône Alpes directorate of the French Office for Biodiversity for their great help during hydrophone installation. We thank Iain McGill for professional proofreading of the English text. Finally, we thank EDF GU de Montpezat for allowing access to the Poutès dam to conduct this experiment.

\section{References}

Aarestrup K, Jepsen N, Rasmussen G, Okland F. 1999. Movements of two strains of radio tagged Altlantic salmon, Salmo salar L., smolts through a reservoir. Fish Manag Ecol 6: 97-107.

Arevalo E, Lassalle G, Tétard S, Maire A, Sauquet E, Lambert P, Paumier A, Villeneuve B, Drouineau H. 2020. An innovative bivariate approach to detect joint temporal trends in environmental conditions: Application to large French rivers and diadromous fish. Sci Total Environ 141260

Babin AB, Ndong M, Haralampides K, Peake S, Jones RA, Curry RA, Linnansaari T. 2020. Migration of Atlantic salmon (Salmo salar) smolts in a large hydropower reservoir. Can J Fish Aquat Sci.

Bach JM, Bruyère F, Poupard PY, Rancon J. 2000. Etude du franchissement (dévalaison - montaison) du complexe hydroélectrique de Poutès - Monistrol par les saumons en 1999. LOGRAMI, Saint Pourçain sur Sioule.

Bach JM, Caut I, Lelièvre M, Viallard J. 2004. Suivi de la dévalaison 2004 des saumoneaux au droit du barrage de Poutès. LOGRAMI, Saint Pourçain sur Sioule.

Bach JM, Leon C, Parouty T, Defours A, Baisez A. 2015. Suivi de la dévalaison 2014 des saumoneaux au droit du barrage de Poutès. LOGRAMI, Saint Pourçain sur Sioule.

Baisez A, Bach J-M., Leon C, Parouty T, Terrade R, Hoffmann M, Laffaille P. 2011. Migration delays and mortality of adult Atlantic salmon Salmo salar en route to spawning grounds on the River Allier, France. Endanger Species Res 15: 265-270.

Birnie-Gauvin K, Aarestrup K. 2019. A call for a paradigm shift: Assumed-to-be premature migrants actually yield good returns. Ecol Freshw Fish 28: 62-68.

Calles O, Karlsson S, Vezza P, Comoglio C, Tielman J. 2013. Success of a low-sloping rack for improving downstream passage of silver eels at a hydroelectric plant. Freshw Biol 58: 2168-2179.

CNSS. 2013. Suivi de la dévalaison dans la zone refuge à l'aide de tambours rotatifs à Alleyras et Chanteuges Année 2013. Conservatoire National du Saumon Sauvage, Chanteuges.

CNSS. 2014. Suivi de la dévalaison dans la zone refuge à l'aide de tambours rotatifs à Alleyras et Chanteuges. Année 2014. Conservatoire National du Saumon Sauvage, Chanteuges.

Courret D, Larinier M. 2008. Guide pour la conception de prises d'eau Ichtyocompatibles pour les petites centrales hydroélectriques. GHAAPPE.

Coutant CC, Whitney RR. 2000. Fish Behavior in Relation to Passage through Hydropower Turbines: A Review. Trans Am Fish Soc 129: $351-380$.

Crozier LG, Hutchings JA. 2014. Plastic and evolutionary responses to climate change in fish. Evol Appl 7: 68-87.

Cuinat R. 1988. Atlantic Salmon in Extensive French River System: Theb Loire-Allier. Atlantic Salmon, Springer., 389-399.

Friedland KD, MacLean JC, Hansen LP, Peyronnet AJ, Karlsson L, Reddin DG, Ó Maoiléidigh N, McCarthy JL. 2009. The recruitment of Atlantic salmon in Europe. ICES J Mar Sci 66: 289-304. 
Gauld NR, Campbell RNB, Lucas MC. 2013. Reduced flow impacts salmonid smolt emigration in a river with low-head weirs. Sci Total Environ 458: 435-443.

Hansen L, Jonsson B, Døving K. 1984. Migration of wild and hatchery reared smolts of Atlantic salmon, Salmo salar L., through lakes. J Fish Biol 25: 617-623.

Haraldstad T, Höglund E, Kroglund F, Haugen TO, Forseth T. 2018. Common mechanisms for guidance efficiency of descending Atlantic salmon smolts in small and large hydroelectric power plants. River Res Appl 34: 1179-1185.

Havn TB, Thorstad EB, Teichert MAK, Sæther SA, Heermann L, Hedger RD, Tambets M, Diserud OH, Borcherding J, Økland F. 2018. Hydropower-related mortality and behaviour of Atlantic salmon smolts in the River Sieg, a German tributary to the Rhine. Hydrobiologia 805: 273-290.

Huusko R, Hyvärinen P, Jaukkuri M, Mäki-Petäys A, Orell P, Erkinaro J. 2018. Survival and migration speed of radiotagged Atlantic salmon (Salmo salar) smolts in two large rivers: one without and one with dams. Can J Fish Aquat Sci 75: $1177-1184$

Imbert H, Martin P, Rancon J, Graffin V, Dufour S. 2013. Evidence of late migrant smolts of Atlantic salmon (Salmo salar) in the LoireAllier System, France. Cybium 37: 5-14.

Isaak DJ, Young MK, Nagel DE, Horan DL, Groce MC. 2015. The cold-water climate shield: delineating refugia for preserving salmonid fishes through the 21st century. Glob Change Biol 21: $2540-2553$

Jepsen N, Aarestrup K, Økland F, Rasmussen G. 1998. Survival of radiotagged Atlantic salmon (Salmo salar L.) and trout (Salmo trutta L.) smolts passing a reservoir during seaward migration. Hydrobiologia 371: 347.

Jonsson B, Jonsson N. 2009. A review of the likely effects of climate change on anadromous Atlantic salmon Salmo salar and brown trout Salmo trutta, with particular reference to water temperature and flow. J Fish Biol 75: 2381-2447.

Jonsson N, Jonsson B. 2014. Time and size at seaward migration influence the sea survival of Salmo salar. J Fish Biol 84: 1457-1473.

Kuczynski L, Chevalier M, Laffaille P, Legrand M, Grenouillet G. 2017. Indirect effect of temperature on fish population abundances through phenological changes. PLoS One 12: e 0175735.

Larinier M, Dartiguelongue J. 1989. La circulation des poissons migrateurs: le transit a travers les turbines des installations hydroélectriques. Bull Fr Pêche Piscic 312-313: 1-94.

Larinier M, Travade F. 2002. Downstream migration: problems and facilities. Bull Fr Pêche Piscic 364 supplément: 181-207.

Larinier M, Dumond L, Lagarrigue T, Frey A, Travade F. 2020. Performance of a large partial-depth guide wall to divert downstream migrating Atlantic salmon smolts at Tuilières dam, Dordogne River. Knowl Manag Aquat Ecosyst 15.

Limburg KE, Waldman JR. 2009. Dramatic declines in North Atlantic diadromous fishes. BioScience 59: 955-965.

Lucas MC, Baras E. 2001. Migration of Freshwater Fishes.

Marschall EA, Mather ME, Parrish DL, Allison GW, McMenemy JR. 2011. Migration delays caused by anthropogenic barriers: modeling dams, temperature, and success of migrating salmon smolts. Ecol Appl 21: 3014-3031.

McCormick SD, Hansen LP, Quinn TP, Saunders RL. 1998. Movement, migration, and smolting of Atlantic salmon (Salmo salar). Can J Fish Aquat Sci 55: 77-92.

McCormick SD, Cunjak RA, Dempson B, O’Dea MF, Carey JB. 1999. Temperature-related loss of smolt characteristics in Atlantic salmon (Salmo salar) in the wild. Can J Fish Aquat Sci 56: 1649-1667.
Minster AM, Bomassi P. 1999. Repérage et évaluation des surfaces potentielles de développement de juvéniles de saumons atlantiques. Proposition d'un modèle de gestion des stocks sur les bassins de l'Allier et de l'Arroux. LOGRAMI/CSP D R6.

Morita K. 2019. Earlier migration timing of salmonids: an adaptation to climate change or maladaptation to the fishery? Can J Fish Aquat Sci 76: 475-479.

Mueller RP, Simmons MA. 2008. Characterization of gatewell orifice lighting at the Bonneville Dam second powerhouse and compendium of research on light guidance with juvenile salmonids. Pacific Northwest National Laboratory (PNNL), Richland, WA (US).

Nyqvist D, Greenberg LA, Goerig E, Calles O, Bergman E, Ardren WR, Castro-Santos T. 2017. Migratory delay leads to reduced passage success of Atlantic salmon smolts at a hydroelectric dam. Ecol Freshw Fish 26: 707-718.

Nyqvist D, Elghagen J, Heiss M, Calles O. 2018. An angled rack with a bypass and a nature-like fishway pass Atlantic salmon smolts downstream at a hydropower dam. Mar Freshw Res 69: 1894-1904.

Otero J, L'Abée-Lund JH, Castro-Santos T, Leonardsson K, Storvik GO, Jonsson B, Dempson B, Russell IC, Jensen AJ, Baglinière J-L. 2014. Basin-scale phenology and effects of climate variability on global timing of initial seaward migration of Atlantic salmon (Salmo salar). Glob Change Biol 20: 61-75.

Ovidio M, Dierckx A, Bunel S, Grandry L, Spronck C, Benitez J-P. 2017. Poor performance of a retrofitted downstream bypass revealed by the analysis of approaching behaviour in combination with a trapping system. River Res Appl 33: 27-36.

Perry RW, Romine JG, Adams NS, Blake AR, Burau JR, Johnston SV, Liedtke TL. 2014. Using a non-physical behavioural barrier to alter migration routing of juvenile chinook salmon in the sacramentosan joaquin river delta. River Res Appl 30: 192-203.

Pracheil BM, DeRolph CR, Schramm MP, Bevelhimer MS. 2016. A fish-eye view of riverine hydropower systems: the current understanding of the biological response to turbine passage. Rev Fish Biol Fish 26: 153-167.

Roy R, Beguin J, Argillier C, Tissot L, Smith F, Smedbol S, De-Oliveira E. 2014. Testing the VEMCO Positioning System: spatial distribution of the probability of location and the positioning error in a reservoir. Anim Biotelemetry 2: 1-7.

Schwinn M, Aarestrup K, Baktoft H, Koed A. 2017. Survival of migrating sea trout (Salmo trutta) smolts during their passage of an artificial lake in a Danish lowland stream. River Res Appl 33: 558-566.

Schwinn M, Baktoft H, Aarestrup K, Lucas MC, Koed A. 2018. Telemetry observations of predation and migration behaviour of brown trout (Salmo trutta) smolts negotiating an artificial lake. River Res Appl 34: 898-906.

Schwinn M, Baktoft H, Aarestrup K, Koed A. 2019. Artificial lakes delay the migration of brown trout Salmo trutta smolts: a comparison of migratory behaviour in a stream and through an artificial lake. J Fish Biol 94: 745-751.

Silva AT, Lucas MC, Castro-Santos T, Katopodis C, Baumgartner LJ, Thiem JD, Aarestrup K, Pompeu PS, O'Brien GC, Braun DC. 2018. The future of fish passage science, engineering, and practice. Fish Fish 19: 340-362.

Stich DS, Bailey MM, Holbrook CM, Kinnison MT, Zydlewski JD. 2015. Catchment-wide survival of wild-and hatchery-reared Atlantic salmon smolts in a changing system. Can J Fish Aquat Sci 72: 1352-1365.

Sykes GE, Johnson CJ, Shrimpton JM. 2009. Temperature and flow effects on migration timing of Chinook salmon smolts. Trans Am Fish Soc 138: 1252-1265.

Teichert N, Benitez J, Dierckx A, Tétard S, de Oliveira E, Trancart T, Feunteun E, Ovidio M. 2020a. Development of an accurate model 
to predict the phenology of Atlantic salmon smolt spring migration. Aquat Conserv Mar Freshw Ecosyst.

Teichert N, Tétard S, Trancart T, Feunteun E, Acou A, de Oliveira E. 2020b. Resolving the trade-off between silver eel escapement and hydropower generation with simple decision rules for turbine shutdown. J Environ Manage 261: 110212.

Tétard S, Lemaire M, De Oliveira E, Martin P. 2016a. Use of 2D acoustic telemetry to study the behaviour of atlantic salmon smolts (Salmo salar) approaching Poutès Dam (Allier River, France). Paper 26123 in, Tétard S, Lemaire M, De Oliveira E, Martin P (eds.). The University of Melbourne, Australia.

Tétard S, Lemaire M, Martin A, De Oliveira E. 2016b. Comportement des smolts de saumon atlantique (Salmo salar) au voisinage du barrage de Poutès (Allier, France). Bilan des études de télémétrie acoustique réalisées en 2014 et 2015. EDF R\&D.

Tétard S, Maire A, Lemaire M, De Oliveira E, Martin P, Courret D. 2019. Behaviour of Atlantic salmon smolts approaching a bypass under light and dark conditions: Importance of fish development. Ecol Eng 131: 39-52.

Thorstad EB, Økland F, Aarestrup K, Heggberget TG. 2008. Factors affecting the within-river spawning migration of Atlantic salmon, with emphasis on human impacts. Rev Fish Biol Fish 18: 345-371.

Thorstad EB, Whoriskey F, Uglem I, Moore A, Rikardsen AH, Finstad B. 2012. A critical life stage of the Atlantic salmon Salmo salar: behaviour and survival during the smolt and initial post-smolt migration. J Fish Biol 81: 500-542.
Thorstad EB, Havn TB, Sæther SA, Heermann L, Teichert MAK, Diserud OH, Tambets M, Borcherding J, Økland F. 2017. Survival and behaviour of Atlantic salmon smolts passing a run-of-river hydropower facility with a movable bulb turbine. Fish Manag Ecol 24: 199-207.

Tomanova S, Courret D, Alric A. 2017. Protecting fish from entering turbines: the efficiency of a low-sloping rack for downstream migration of Atlantic salmon smolts. La Houille Blanche 1: 11-13.

Tomanova S, Courret D, Alric A, De Oliveira E, Lagarrigue T, Tétard S. 2018. Protecting efficiently sea-migrating salmon smolts from entering hydropower plant turbines with inclined or oriented low bar spacing racks. Ecol Eng 122: 143-152.

Venditti DA, Rondorf DW, Kraut JM. 2000. Migratory behavior and forebay delay of radio-tagged juvenile fall Chinook salmon in a lower Snake River impoundment. North Am J Fish Manag 20: $41-52$.

Whalen KG, Parrish DL, McCormick SD. 1999. Migration timing of Atlantic salmon smolts relative to environmental and physiological factors. Trans Am Fish Soc 128: 289-301.

Williams JG, Armstrong G, Katopodis C, Larinier M, Travade F. 2012. Thinking like a fish: a key ingredient for development of effective fish passage facilities at river obstructions. River Res Appl 28: 407-417.

Winter J. 1996. Advances in underwater biotelemetry. Fish Tech 2nd Ed Am Fish Soc Bethesda Md 555-590.

Cite this article as: Tétard S, Roy R, Teichert N, Rancon J, Courret D. 2021. Temporary turbine and reservoir level management to improve downstream migration of juvenile salmon through a hydropower complex. Knowl. Manag. Aquat. Ecosyst., $422,4$. 